\title{
QRIS DI MATA UMKM: EKSPLORASI PERSEPSI DAN INTENSI UMKM MENGGUNAKAN QRIS
}

\author{
I Wayan Arta Setiawan ${ }^{1}$ \\ Luh Putu Mahyuni ${ }^{2}$
}

\author{
Fakultas Ekonomi dan Bisnis, Universitas Pendidikan Nasional ${ }^{1,2}$ \\ Email : artabusiness99@gmail.com¹ mahyuniluhputu@undiknas.ac.id ${ }^{2}$
}

\begin{abstract}
This study aims to explore the perceptions of small medium enterprises (SMEs) toward QRIS and the factors that influence their intention to use QRIS. Technology acceptance model and theory of planned behavior were used to guide the process of developing interview questions and data analysis. Data were collected through in-depth semi-structured interviews with 16 SMEs living in Denpasar and then analyzed through coding and theming process. This study indicates that SMEs have positive perceptions toward QRIS, as an alternative method of payment that very easy to use and could minimize physical contact. This study also finds that the intention of SMEs to use QRIS are affected by: (1) Positive perceptions toward QRIS; (2) The influence of customers, close friends, and influencers; (3) Perceived barriers to use QRIS, such as the quality of internet connection, the cost and transaction limit. This study offers a comprehensive model to understand factors that influence SMEs intention to use QRIS. This model can be used as a reference to further develop survey instrument and empirically test the model. The findings of this study can also be used as a reference for bank and non-bank financial institutions in determining the appropriate strategy to attract SMEs to use QRIS.
\end{abstract}

Keywords: Small Medium Enterprises; Perceptions toward QRIS; Intention to Use QRIS; Technology Acceptance Model; Theory of Planned Behavior

\begin{abstract}
ABSTRAK
Penelitian ini bertujuan mengeksplorasi bagaimana persepsi UMKM terhadap QRIS serta faktor-faktor yang mempengaruhi intensinya menggunakan QRIS. Technology acceptance model dan theory of planned behavior digunakan sebagai panduan dalam proses penyusunan pertanyaan wawancara dan analisis data. Data dikumpulkan melalui proses wawancara mendalam semi-terstruktur yang melibatkan 16 pelaku usaha (UMKM) yang tinggal di kota Denpasar. Data kemudian dianalisis melalui proses coding dan theming. Penelitian ini mengindikasikan bahwa UMKM memiliki persepsi positif terhadap QRIS, sebagai alternatif cara pembayaran yang mudah dan dapat mengurangi kontak fisik. Penelitian ini juga menemukan bahwa intensi UMKM menggunakan QRIS dipengaruhi oleh: 1. Persepsi positif terhadap QRIS; 2. Pengaruh pihak luar, antara lain pembeli, teman dekat, dan para influencer; 3. Persepsi hambatan menggunakan QRIS, antara lain kualitas koneksi internet, biaya penggunaan, dan batas transaksi. Penelitian ini menawarkan sebuah model komprehensif untuk memahami faktor-faktor yang mempengaruhi intensi UMKM menggunakan QRIS. Model ini dapat dijadikan sebagai acuan bagi penelitian berikutnya untuk mengembangkan instrumen survey dalam upaya mendapatkan bukti empiris yang dapat digeneralisasi terkait faktor-faktor yang mempengaruhi intensi UMKM menggunakan QRIS. Selain itu, penelitian ini juga dapat dijadikan sebagai sumber referensi berharga bagi lembaga bank atau non-bank untuk merumuskan strategi yang tepat menarik UMKM menggunakan QRIS.
\end{abstract}

Kata kunci: Usaha Kecil Menengah; Persepsi terhadap QRIS; Niat Menggunakan QRIS; Technology Acceptance Model; Theory of Planned Behavior 


\section{PENDAHULUAN}

The Rockefeller Foundation mengulas keadaan ekonomi dunia akibat pandemi Covid-19, "Bahkan negara yang maju, kewalahan dengan adanya pandemi yang dialami seluruh dunia, yang telah menginfeksi hampir 20 persen dari populasi global dan membunuh 8 juta orang hanya dalam tujuh bulan, sebagian besar dari mereka adalah orang dewasa yang muda serta sehat. Pandemi juga memiliki efek mematikan pada sektor ekonomi: mobilitas international baik orang maupun barang terhenti, melemahkan industri seperti pariwisata dan memutus rantai pasokan global (global supply chains) (Rockefeller, 2010)”. Pandemi Covid-19 mengguncang perekonomian seluruh negara, tidak terkecuali Indonesia. Pada krisis keuangan 1998 yang dialami Indonesia, usaha mikro kecil menengah (UMKM) pada saat itu mampu bertahan dan menjadi penyokong perekonomian. Akan tetapi pada saat ini bahkan UMKM pun sulit bertahan.

UMKM dipaksa untuk bisa segera berinovasi dan beradaptasi, antara lain dengan mengadopsi model bisnis digital. Hingga saat ini terdapat 132 juta pengguna internet di Indonesia (Kasali, 2018). Industri fintech (financial technology) berupaya mengoptimalkan potensi tersebut dengan menawarkan berbagai bentuk produk keuangan yang memberi kemudahan bagi penggunanya untuk mengakses berbagai layanan keuangan. Produk-produk keuangan digital itu antara lain Go-Pay, Ovo, Dana, dan sebagainya. Selain itu, terdapat pula alternatif pembayaran menggunakan QRIS. 
QRIS memberikan alternatif metode pembayaran non-tunai secara lebih efisien (goleman, daniel; boyatzis, Richard; Mckee \& Perdana, 2018). Melalui pengunaan satu standar $Q R$ Code, penyedia barang dan jasa (merchant) tidak perlu memiliki berbagai jenis $Q R$ Code dari penerbit yang berbeda. Hingga akhir Februari 2020, jumlah merchant yang menggunakan QRIS di Provinsi Bali tercatat sebanyak lebih dari 65 ribu, jumlah ini meningkat sebesar 5 persen dalam periode satu bulan. Penggunaan QRIS menjadi trend positif belakangan ini bagi pelaku usaha dan juga konsumen. Mengingat manfaatnya dalam membantu proses transaksi non-tunai secara lebih efisien, penggunaan QRIS oleh UMKM akan dapat membantu meningkatkan kinerja usahanya, terlebih pada masa pandemi seperti saat ini. Hingga saat ini, belum banyak UMKM yang telah menggunakan QRIS, sehingga penelitian perlu dilakukan untuk mengeksplorasi faktor-faktor yang mempengaruhi intensi UMKM menggunakan QRIS. Dengan mengetahui faktor pembentuk intensi UMKM menggunakan QRIS, diharapkan akan dapat dirumuskan strategi yang tepat untuk mendorong lebih banyak UMKM menggunakan QRIS. Dengan demikian, pertanyaan penelitian ini adalah faktorfaktor apa sajakah yang mempengaruhi intensi UMKM dalam mengunakan QRIS?

Mengapa UMKM tertarik menggunakan QRIS? UMKM adalah jenis usaha produktif yang dimiliki orang perorang atau badan dengan ketentuan penghasilan sesuai dengan undang-undang (UU No. 20 Tahun 2008, 2008). Sebagai usaha penyedia barang dan jasa, UMKM pada umumnya menyebar di beberapa wilayah baik perkotaan dan pedesaan. UMKM juga memiliki peran 
penting dan bersifat dinamis. Jenis usaha ini memiliki porsi sebesar 99,99\% dari total seluruh jenis usaha di Indonesia atau 56,54 juta unit (Sarwono, 2015). UMKM mampu bertahan ketika badai krisis moneter melanda Indonesia pada tahun 1998. Pada situasi pandemi saat ini, kemampuan UMKM untuk bertahan kembali diuji (Suci et al., 2017).

Menyikapi masalah tersebut, UMKM ke depan perlu menjalin hubungan antara pihak terkait untuk memecahkan masalah yang masih menghambat UMKM. Dalam hal ini, pemerintah dan khusunya Kemenkop dan UKM perlu terus menerus melakukan upaya mewujudkan UMKM yang berdaya saing digital. Keterlibatan pemerintah daerah dan pihak-pihak eksternal lain seperti perbankan, dan asosiasi/peguyuban menjadi aspek penting bagi UMKM untuk berakselerasi dalam adaptasi memanfaatkan berbagai peluang di sistem ekonomi digital saat ini (Mangeswuri et al., 2018).

Disisi lain, UMKM memiliki strategi dalam mencapai tujuan. Strategi merupakan tindakan untuk mengupayakan terjadinya peningkatan usaha secara terus menerus dengan cara memenuhi apa yang diharapkan para pelanggan di masa kini maupun masa mendatang (Prahalad, 1995), termasuk menyediakan barang dan jasa yang dibutuhkan. UMKM juga memanfaatkan media sosial sebagai sarana promosi dan sebagai bukti eksistensi usaha dalam membangun brand image. Dengan jangkauan informasi yang luas ini menyebabkan UMKM memiliki daya saing yang lebih besar. Di tengah persaingan yang begitu ketat, sangat dibutuhkan penyesuaian strategi secara cepat untuk merespon perubahan 
situasi dan kondisi. Agar tetap kompetitif, UMKM berfokus pada upaya membangun sinergi, memanfaatkan kopetensi dasar dan memberikan nilai tambah bagi pelanggan (Richard L. Daft, 2010).

UMKM memperoleh informasi mengenai trend usaha melalui berbagai media sosial. Kemajuan teknologi informasi dan komunikasi saat ini sangat memudahkan UMKM dalam melakukan perencanaan dan pengembangan usahanya. Menurut (Mangeswuri et al., 2018; Modelski \& Devezas, 2007) ekonomi digital merupakan sistem ekononomi yang kompleks dan merupakan fenomena yang baru muncul terkait dengan aspek-aspek ekonomi mikro, ekonomi makro dan teori organisasi serta administrasi atau dengan kata lain "Virtual bisnis benar-benar dilakukan, nilai dibuat dan dipertukarkan serta transaksi terjadi dalam hubungan satu dengan satu yang matang dengan menggunakan apa saja termasuk inisiatif internet sebagai alat tukar".

Akibat pekembangan baru dalam bidang digitalisasi tersebut, sikap dan gaya hidup masyarakat berubah menjadi peka dan kritis terhadap setiap perubahan, yang kemudian menciptakan bentuk interkonektivitas baru antarpelaku ekonomi yang menjadi semakin kreatif, aktif dan produktif. Selain perkembangan industri atau ekonomi kreatif, perkembangan teknologi digitalisasi juga merubah sistem pembayaran dari sistem pembayaran tunai ke non tunai menggunakan electronic money atau uang elektronik. Berdasarkan Bank for International Settlements, e-money didefinisikan stored-value atau prepaid produk dimana catatan dana atau value yang tersedia untuk konsumen dan 
produsen disimpan pada perangkat elektronik yang dimiliki (Mangeswuri et al., 2018; Secretariat, 2000).

Melihat kondisi tersebut, Bank Indonesia yang memiliki tugas menentukan kebijakan moneter dan mengatur sistem pembayaran telah mengeluarkan kebijakan sistem melalui QRIS yang diatur dalam Peraturan Bank Indonesia No.16/08/PBI/2014 (Bank Indonesia, 2014). Dengan adanya alat pembayaran non-tunai seperti QRIS ini diharapkan mampu mengoptimalkan daya beli masyarakat yang sekaligus berdampak pada meningkatnya perekonomian negara. Hal ini karena QRIS sendiri memberi kemudahan dan keamanan bagi UMKM dalam sebagai pengguna QRIS. Kemudahan dan keamanan yang diberikan salah satunya adalah UMKM tidak perlu membawa uang tunai secara langsung dalam jumlah yang banyak untuk bertransaksi (Mangeswuri et al., 2018).

Selain perkembangan dalam alat pembayaran nontunai melalui QRIS, berbagai perusahaan dan/atau industri juga melakukan transformasi dengan menerapkan teknologi informasi dan komunikasi keuangan atau yang lebih dikenal fintech (financial technology). Keberadaan fintech bertujuan untuk membuat UMKM lebih mudah mengakses produk-produk keuangan, mempermudah transaksi dan juga meningkatkan literasi keuangan (Carlsson \& Gustavsson, 2001; Mangeswuri et al., 2018). Suatu sistem pembayaran elektronik yang mudah dipahami, digunakan, memiliki tolak ukur jelas terhadap nilai tambah bagi pengguna dan akan lebih dipercaya oleh pengguna (Richard L. Daft, 2010). 
Sistem pembayaran elektronik dikatakan mudah digunakan apabila dapat meningkatkan produktivitas dan membuat proses pembayaran lebih efektif dan efisien (Gefen et al., 2003; Yahyapour, 2008).

Ezeh \& Nwankwo, (2018) menemukan bahwa persepsi akan kemudahan dalam penggunaan, persepsi akan biaya dan jumlah informasi tersedia terkait pembayaran digital berpengaruh penting terhadap niat pelanggan dalam menggunakan pembayaran digital. Akan tetapi, manfaat yang dirasakan, persepsi kredibilitas, ekspresi dan juga self-efficacy tidak mampu memprediksi niat pelanggan dalam menerima pembayaran digital. Khalil Md Nor \& Pearson, (2007) dalam penelitiannya menunjukan bahwa kepercayaan, keunggulan relatif serta kemampuan dalam proses uji coba sangat berpengaruh terhadap pengguna fasilitas pembayaran melalui internet banking.

Penelitian ini menggunakan kombinasi antara technology acceptance model (TAM) dan theory of planned behaviour (TPB) untuk membantu proses eksplorasi lebih mendalam terkait faktor-faktor yang mempengaruhi intensi UMKM menggunakan QRIS.

Technology Acceptance Model. Dalam perkembangan teknologi yang pesat, muncul teori yang awalnya dibangun oleh Davis, Bangozzi, dan Warshaw di tahun 1986 yang dikenal dengan technology acceptance model (TAM). TAM dikembangkan untuk menganalisa dan memahami faktor-faktor yang mungkin mempengaruhi diterimanya penggunaan sebuah teknologi. Menurut TAM, 
persepsi kegunaan dan kemudahan penggunaan suatu teknologi akan mempengaruhi niat untuk menggunakan teknologi tersebut. Niat ini kemudian mempengaruhi penggunaan nyata suatu teknologi. Persepsi manfaat dan persepsi kemudahan penggunaan suatu teknologi ditemukan sebagai variabel yang signifikan dan penting dalam mempengaruhi penggunaan suatu teknologi (Davis, 1989). Gambar 1 berikut menunjukan model TAM.

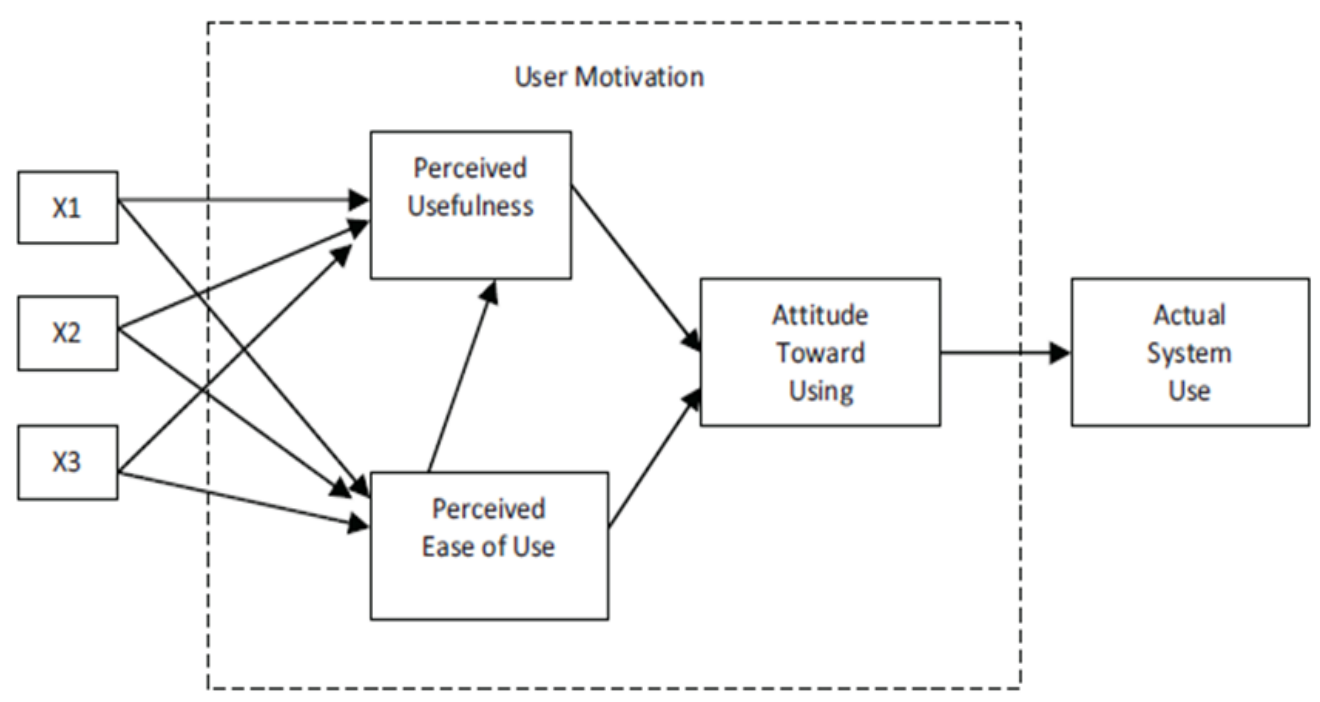

Gambar 1:

Model technology acceptance model (TAM)

Theory of planned behaviour merupakan pengembangan dari theory of reasoned action. TPB adalah kerangka berpikir konseptual bertujuan untuk menjelaskan determinan perilaku tertentu. Perilaku individu dipengaruhi oleh niat individu (behavior intention) terhadap perilaku tertentu. Niat dalam berprilaku dipengaruhi oleh tiga faktor yaitu, sikap terkait perilaku (attitude toward the behavior), norma subyektif (subjective norm), dan persepsi kontrol keprilakuan (percieve behavior control) (Ajzen, 1991). 
Theory of planned behavior dibangun untuk menjelaskan perilaku yang dihasilkan dari proses pengambilan keputusan secara sadar dan berdasarkan pertimbangan tertentu, dimana si pengambil keputusan memiliki suatu derajat kendali atas keputusan yang akan diambil (volitional control), terutama dalam hal psikomotor, kognitif, persepsi dan atribusi orang (Ajzen, 1991; Heider, 1944). Gambar 2 berikut menggambarkan model dari TPB.

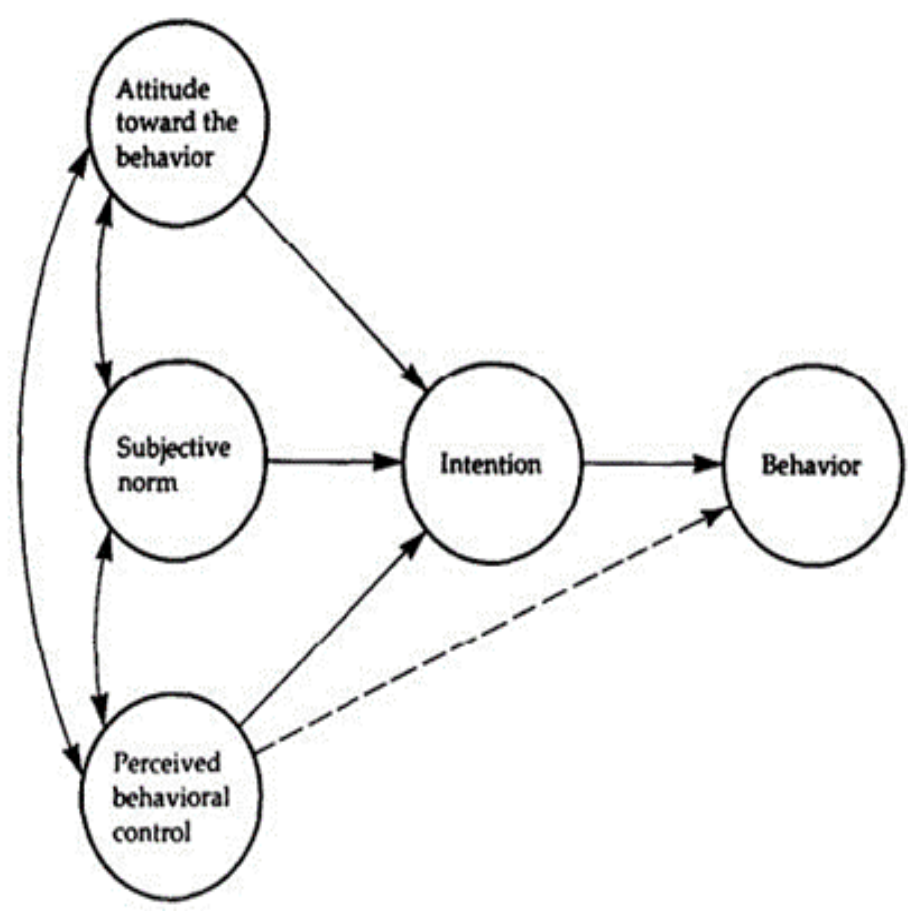

Gambar 2.

Model Theory of planned behavior

Penelitian ini menggunakan kerangka teori yang merupakan gabungan dari TAM dan TPB untuk membantu memberikan panduan dalam proses eksplorasi mendalam atas faktor-faktor yang mempengaruhi intensi UMKM menggunakan QRIS. Gambar 3 berikut menggambarkan kerangka teori yang digunakan sebagai panduan dalam menyusun pertanyaan wawancara dan 
melakukan analisis data.

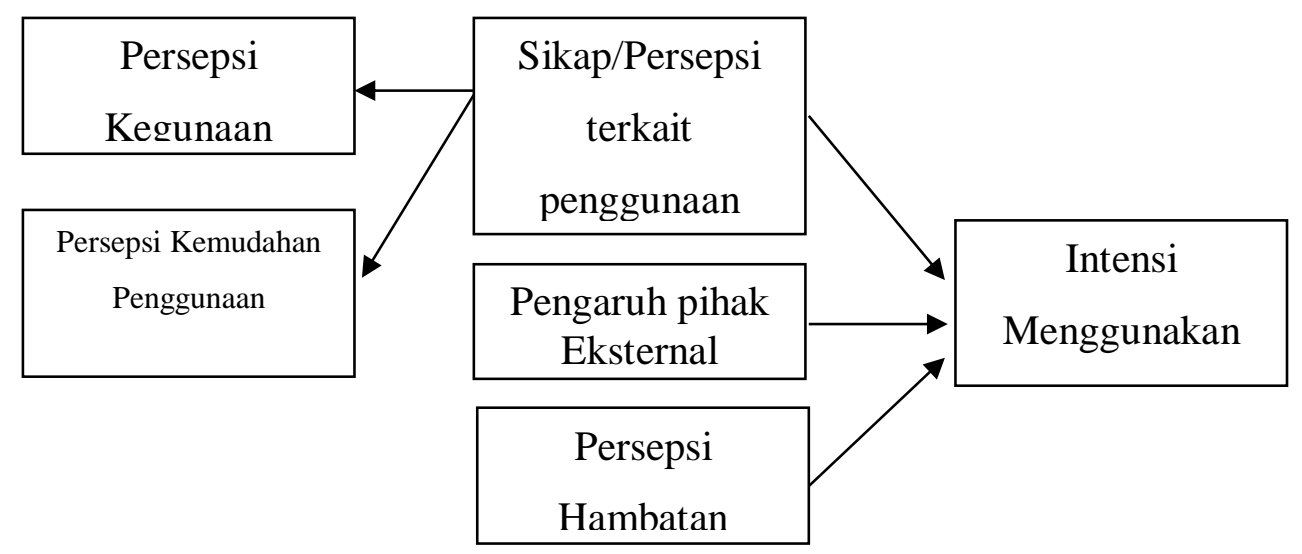

Gambar 3.

Kerangka Teori Penelitian

\section{METODE PENELITIAN}

Untuk menjawab pertanyaan penelitian, wawancara semi-terstruktur dan mendalam dilakukan terhadap 16 pelaku usaha (UMKM), di beberapa wilayah yang berbeda di Bali. Strategi pengambilan sampel menggunakan maximum variation sampling, yang bertujuan menangkap/menggambarkan tema sentral dari studi melalui informasi yang berbeda dari berbagai tipe/karakteristik berbeda (usia, tingkat pendidikan, gender, omzet usaha, dan tempat tinggal baik kota besar/pinggiran) (Sahni \& Slamet, 2006).

Daftar pertanyaan wawancara dibangun berdasarkan theory of planned behaviour (Ajzen, 1991) dan technology acceptance model theory (Davis, 1989). Secara garis besar terdapat empat pertanyaan inti: 1. Apakah Bapak/Ibu mengetahui tentang QRIS?; 2. Apakah Bapak/Ibu menggunakan QRIS dalam 
transaksi bisnis? Jika ya, bisa dijelaskan lebih detail penggunaanya? Jika tidak, apakah berminat menggunakan QRIS?; 3. Apakah QRIS berguna dalam mendukung bisnis Bapak/Ibu? Jika ya, mohon disebutkan \& dijelaskan apa saja kegunaanya? Jika tidak, mohon dijelaskan mengapa?; 4. Apakah menurut Bapak/Ibu mudah menggunakan QRIS? Jika ya, mohon dapat dijelaskan. Jika tidak, mengapa? Mohon dapat dijelaskan; 5. Apakah ada pihak luar diri/pihak yang mempengaruhi keputusan/minat Bapak/Ibu menggunakan QRIS? Mohon dijelaskan; 6. Apakah ada faktor-faktor yang kira-kira dapat menghambat Bapak/Ibu menggunakan QRIS? Apakah ada faktor yang menjadi kendala dalam menggunakan QRIS?

Wawancara dilakukan dalam durasi rata-rata 30 menit. Proses wawancara direkam dengan perekam audio atas seijin partisipan. Data audio kemudian diubah menjadi transkrip wawancara. Transkrip wawancara dibaca dengan teliti dan hati-hati untuk menentukan kode yang dapat mewakili beberapa ide/pemikiran serupa. Beberapa tema dan kemungkinan adanya hubungan antar tema diidentifikasi untuk merumuskan suatu model yang dapat menggambarkan fenomena yang diteliti. Proses tersebut disebut dengan proses coding dan theming (Saldaña, 2013). Dalam penelitian ini, proses coding dan theming dipandu oleh theory of planned behaviour dan technology acceptance model theory (Ajzen, 1991; Davis, 1989). Kutipan-kutipan penting yang mewakili kode tertentu didokumentasikan dalam kode yang sesuai, sebagai pemaparan dalam hasil. Untuk menjaga prinsip anonimitas dan membuat penyusunan laporan lebih efektif dan efisien, partisipan diberi kode I1 sampai I16. Setiap kutipan yang ditunjukan 
dalam pemaparan hasil diakhiri menggunakan kode partisipan yang menyatakan pernyataan tertentu.

\section{HASIL DAN PEMBAHASAN}

Analisis hasil wawancara menunjukan bahwa sebagian besar partisipan yang diwawancarai menyatakan memiliki niat yang cukup kuat untuk menggunakan QRIS. Secara umum, penelitian ini menemukan lima faktor/tema utama yang menjelaskan intensi/minat UMKM menggunakan QRIS. Faktor itu adalah faktor persepsi manfaat yang dirasakan, persepsi kemudahan, persepsi kegunaan, pengaruh pihak luar, dan persepsi hambatan untuk menggunakan QRIS. Berikut adalah penjelasan lebih detai dari masing-masing faktor tersebut.

Persepsi manfaat yang dirasakan UMKM terhadap QRIS. Secara umum terdapat tiga kode yang terkait persepsi kegunaan QRIS terhadap UMKM, yaitu: 1.1 Sangat menguntungkan; 1.2 Memberi alternatif metode pembayaran; dan 1.3 Menggurangi kontak fisik.

Sangat menguntungkan.UMKM dalam penelitian ini cenderung mengidentifikasi QRIS sebagai media pembayaran yang mengguntungkan, serta dipandang lebih sederhana dalam penggunaannya. Sebagaimana dinyatakan I10, "menguntungkan"(I10), Pernyataan senada namun lebih mendalam disampaikan oleh I12, "QRIS ini sangat menguntungkan selain simple dan juga lebih aman" (I12). Beberapa penelitian sebelumnya juga mengkonfirmasi keuntungan penggunaan $Q R$ code dalam transaksi. $Q R$ code menawarkan peningkatan kualitas layanan, pengurangan biaya transaksi, desain layanan yang bervariasi dan stabil 
(Lee \& Shin, 2018). Penggunaan $Q R$ code juga memungkinkan terjadinya kolaborasi layanan dalam proses mempromosikan bisnis dan untuk meningkatkan pendapatan usaha secara cepat (Clarysse et al., 2014; Paula Graça, 2017). Pembayaran non tunai juga lebih cepat dalam menyelesaian pembayaran, efisien dan memberi keuntungan dalam bentuk diskon yang dapat digunakan merchantmerchant tertentu (Ahriana et al., 2016).

Memberi alternatif metode pembayaran. Mengingat seluruh partisipan merupakan UMKM yang berlokasi ditempat yang berbeda seperti ada di pusat perkotaan dan di pinggir kota dan berada dalam wilayah pariwisata maka tak mengherankan apabila alternatif pembayaran memiliki peran penting seperti dinyatakan oleh I8, "Karena nggak perlu ngumpulin uang receh"(I8), Hal serupa dinyatakan oleh I9, "Karena biasa pake mobile banking, cara kerjanya pakai handphone" (I9), serta I10, "Jadi kita ngak usah repot-repot sediakan recehan, dan lebih efisien waktu begitu" (I10), dan di pertegas dari pernyataan I11, I12, I13 dan I15 sebagai berikut, ".....maka umkm-umkm menggunakan QRIS untuk alternatif pembayaran"(I11), "Jadi menurut saya sih iya karena memudahkan para customer"(I12), "alat pembayaran yg efisien dan aman"(I13), "karena orang-orang jarang pakai cash dan lebih sederhana untuk pembayaran" (I15). Beberapa penelitian sebelumnya juga mengungkapkan manfaat $Q R$ code sebagai alternatif metode pembayaran (Popovska-Kamnar, 2014; Shy, 2019).

Menggurangi kontak fisik.Menginggat kondisi pandemi yang tersebar di beberapa wilayah lokasi partisipan dalam penelitian ini, banyak UMKM mengalihkan metode pembayarannya untuk mengurangi kontak langsung dengan 
pelanggan saat membayar seperti dinyatakan oleh I10, "kayak yang kita tau sekarang kan ada covid, jadi QRIS ini bisa jadi solusi" (I10), di imbuhi oleh I11 "karena kondisi pandemi saat ini yang mendorong saya menggunakan QRIS"(I11), serta diperjelas oleh I12, "karena kondisi sekarang juga memaksa saya menggunakan QRIS"(I12). Bank Indonesia mengkonfirmasi bahwa pemakaian uang elektronik dapat menggurangi kontaminasi penyakit yang disebabkan kuman dalam uang. QRIS memfasilitasi proses transaksi dengan barcode yang memiliki fleksibilitas dalam pembayaran (Bank Indonesia, 2006).

Persepsi kemudahan penggunaan QRIS. Secara umum terdapat tiga kode yang terkait persepsi penggunaan QRIS terhadap UMKM, yaitu: 2.1 Sangat mudah digunakan; 2.2 Memudahkan pembayaran; dan 2.3 Hanya tinggal ditempel di kasir.

Sesuai pernyataan oleh I10, "Simple, iya saya mengunakan QRIS, mudah banget seperti itu" (I10), dan diperjelas oleh pernyataan I13, "Bermanfaat kalau untuk pembayaran karena simple" (I13). Selanjutnya I11 menyatakan,"mmm, setau saya sistem sama seperti ovo, gopay, link aja, nggak sulit ya makenya"(I11). Informan lain menjelaskan mengapa QRIS dipandang mudah digunakan. I13 menyatakan,"Cepat, efisien dan simple untuk pembayaran" (I13). Penggunaan QRIS dipandang tidak membutuhkan banyak proses dan lebih efektif. Penelitian sebelumnya menjelaskan bahwa teknologi yang banyak dipilih untuk digunakan memiliki karakteristik mudah dan efisien untuk (Chakravorti \& Jankowski, 2005; Ferdiana \& Darma, 2019). 
Pemahaman akan QRIS. Secara umum terdapat tiga kode yang terkait persepsi pemahaman dan persepsi kegunaan akan QRIS terhadap UMKM, yaitu: 3.1 Kode batang digital; 3.2 Pencatatan transaksi otomatis; dan 3.3 Pembayaran digital.

Beberapa UMKM menyatakan bahwa QRIS merupakan sejenis barcode. Sebagaimana dinyatakan I12, "Jadi QRIS itu QRcode yang di buat BI untuk orang memudahkan transaksi"(I12), dan di perjelas lagi oleh pernyataan I13, "Saya mengetahui tentang QRIS sejenis barcode berbentuk pola persegi"(I13). Bank Indonesia menjelaskan bahwa QRIS merupakan barcode dengan dua dimensi yang mengandung informasi dan dapat dibaca dari berbagai arah horizontal (Bank Indonesia, 2019).

Sebagian besar UMKM memahami QRIS sebagai alat pembayaran digital yang dapat dilakukan melalui handphone seperti yang dinyatakan oleh I10, "Kayak pembayaran dari konsumen pakai barcode"(I10), ditambahkan oleh I13, "Barcode untuk sistem pembayaran masa kini"(I13). Penelitian sebelumnya mengungkapkan bahwa variasi layanan sejenis QRIS sangat penting sebagai kelangsungan usaha di negera-negara berkembang khususnya bagi UMKM. Metode pembayaran semacam QRIS dipandang sebagai inovasi dalam mekanisme pembayaran digital (Jenkins, n.d.).

Beberapa UMKM yang terlibat dalam penelitian ini menilai QRIS berperan dalam membantu mereka dalam melakukan pencatatan otomatis/akuntansi digital yang muncul dalam history of transaction seperti 
dinyatakan oleh I13, "Pembayaran bisa dibuka dari QRIS karena dicatat otomatis" (I13), diperkuat pernyataan I15, "Ngak perlu hitung-hitung uang manual, ngak perlu akuntansi"(I15). Penelitian sebelumnya mengungkapkan bahwa fasilitas direct feeds yang diberikan QRIS sangat memudahkan untuk melihat kecocokan antara pemasukan dan pengeluaran (Setiawan et al., 2018).

Pengaruh Eksternal UMKM menggunakan QRIS. Secara umum terdapat tiga kode yang terkait persepsi pengaruh Eksternal menggunakan QRIS terhadap UMKM, yaitu: 4.1 Tokoh terkenal; 4.2 Teman dekat; dan 4.3 Pembeli. Ketika ditanyakan mengenai pihak eksternal yang mempengaruhi niat partisipan dalam menggunakan QRIS, partisipan menyebutkan terdapat pengaruh tokoh terkenal, konsumen, dan teman dekat dalam pengambilan keputusan penggunaan QRIS. Informan I10 menyatakan, "Saya juga dengar dari orang yang sudah sukses menggunakan QRIS, jadi saya berminat" (I10). Pengaruh pembeli menjadi hal yang begitu signifikan dimana rata-rata penjual menyesuaikan diri dengan kebiasaan pembeli, dalam hal ini terkait metode pembayaran seperti dinyatakan oleh I12, "Biasa orang kan pake mobile banking juga, selain itu banyak konsumen bertanya soal QRIS dibanding pembayaran lainya"(I12).

Informan lain menjelaskan pengaruh teman dekat seperti dinyatakan oleh I9, "Pastinya kayak temen saya juga yang mempengaruhi, ada sharing informasi, jadi terpengaruh teman menggunakan QRIS" (I9). Pernyataan ini didukung oleh I15, "Pastinya, pengaruh teman-teman memberi referensi dan informasi" (I15). Pengaruh orang terdekat seperti keluarga atau teman dalam merekomendasikan, menggunakan dan mendukung dalam menggunakan $e$ - 
money juga ditemukan dalam penelitian sebelumnya (Suwandi \& Azis, 2018). Penelitian lain mengkonfirmasi adanya social influence dalam mendorong atau mempengaruhi keputusan penggunaan electronic payment dalam transaksi (Martins et al., 2014; Oye et al., 2014; Venkatesh et al., 2016). Signifikansi pengaruh pelanggan dalam penentuan keputusan penjual menggunakan pembayaran digital semacam QRIS juga ditemukan dalam beberapa penelitian terdahulu (Dahlberg et al., 2008, 2015; Duncombe, 2011; Evans et al., 2017; Teja, 2017). Persepsi Hambatan menggunakan QRIS. Secara umum terdapat tiga kode yang terkait persepsi hambatan menggunakan QRIS terhadap UMKM, yaitu Koneksi/jaringan internet, Biaya Penggunaan, dan Limit transaksi.

Penelitian ini mengungkap beberapa faktor penghambat dalam intensi menggunakan QRIS, yaitu koneksi internet yang tidak stabil, pengenaan biaya penggunaan QRIS, dan terdapatnya limit transaksi QRIS. Sebagaimana dijelaskan oleh I8, "Mungkin pada saat mati lampu gitu nggak ada sinyal, pada saat kehabisan kuota begitu, itu penghambatnya salah satunya"(I8). Pernyataan ini didukung I10, "Hmm.....mungkin koneksi internet yaa"(I10). World Economic Forum mengungkapkan bahwa sebagian besar transaksi di negaranegara berkembang memiliki nilai rendah namun volume yang tinggi. Dibutuhkan investasi awal yang besar akan peralatan dan infrastruktur jaringan/koneksi internet serta sumber daya untuk mendukung volume transaksi yang tinggi (World Economic Forum, 2015).

Faktor biaya penggunaan QRIS menjadi perhatian informan dalam penelitian ini. Sebagaimana dijelaskan oleh I9, "Iya mungkin, kalo bisnis agak 
besar boleh lah pake QRIS, karena kan ada biayanya" (I19). I15 menjelaskan, "Kalau untuk menggunakan QRIS belum ya karena usaha masih kecil dan belum stabil"(I15). Selain faktor biaya, limit transaksi juga menjadi perhatian informan penelitian ini. Tabel 1 berikut menampilkan ringkasan kode dan tema yang diidentifikasi dalam penelitian ini. Gambar 4 menunjukkan model yang dapat diidentifikasi dari hasil analisis kualitatif penelitian ini.

Tabel 1.

Ringkasan kode dan tema hasil analisis kualitatif

\begin{tabular}{ll}
\hline Tema dan Kode & Jumlah Respon \\
\hline Tema 1: Persepsi manfaat yang dirasakan UMKM terhadap QRIS & 2 \\
Kode 1.1: Sangat menguntungkan & 7 \\
Kode 1.2: Alternatif metode pembayaran & 3 \\
Kode 1.3: Mengurangi kontak fisik & \\
\hline Tema 2: Persepsi kemudahan penggunaan QRIS & 6 \\
Kode 2.1: Sangat mudah digunakan & 2 \\
Kode 2.2: Memudahkan pembayaran & 2 \\
Kode 2.3: Hanya tinggal ditempel di kasir & \\
\hline Tema 3: Pemahaman akan QRIS & 7 \\
Kode 3.1: Kode batang digital & 3 \\
Kode 3.2: Pencatatan transaksi otomatis & 2 \\
Kode 3.3: Pembayaran digital & \\
\hline Tema 4: Pengaruh Eksternal UMKM menggunakan QRIS & 9 \\
Kode 4.1: Tokoh terkenal & 5 \\
Kode 4.2: Teman dekat & 8 \\
Kode 4.3: Pembeli & 11 \\
\hline Tema 5: Persepsi Hambatan menggunakan QRIS & 2 \\
Kode 5.1: Koneksi/jaringan internet & 3 \\
Kode 5.2: Biaya Penggunaan & \\
Kode 5.3: Limit transaksi & \\
\hline
\end{tabular}

Sumber : Data diolah, 2020 


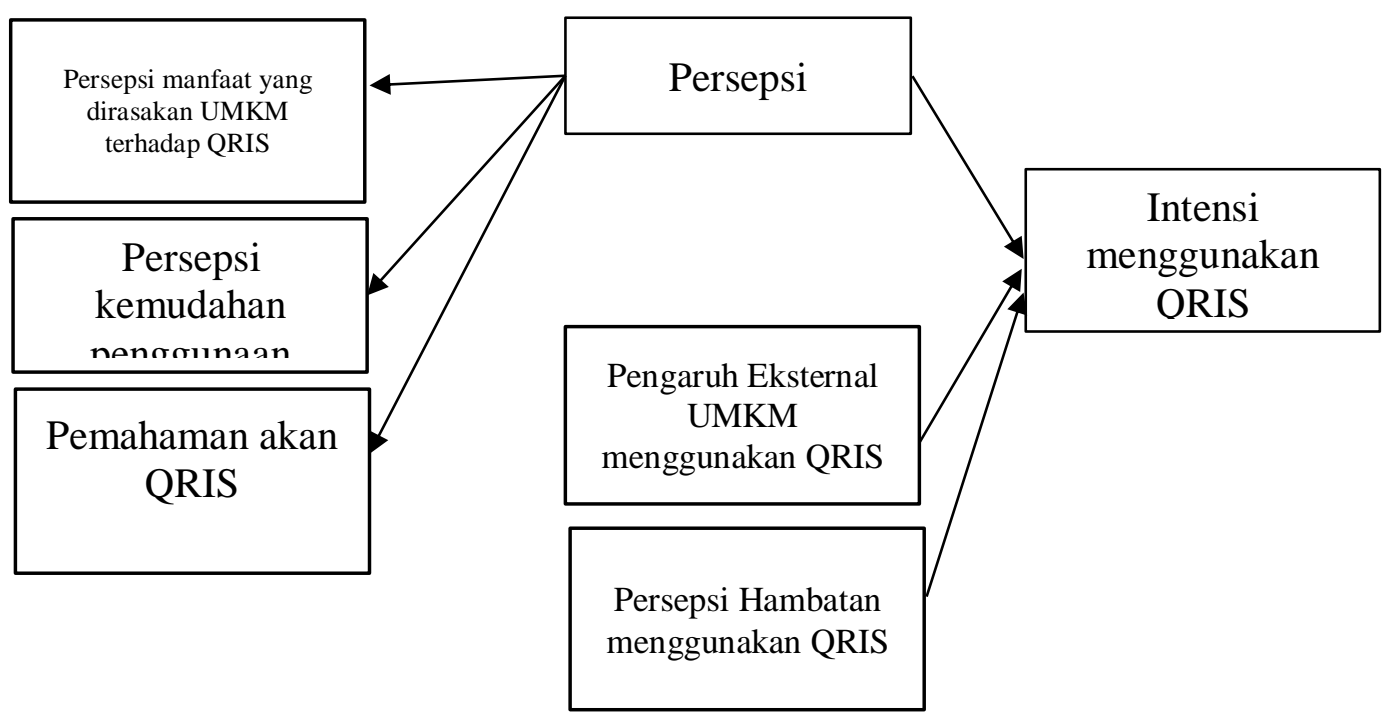

Gambar 4.

Model Hubungan Antar Tema Hasil Analisis Kualitatif

Penelitian ini mengindikasikan bahwa UMKM memiliki persepsi positif terhadap QRIS. Dari penjelasan yang diberikan terkait persepsi ini, tersirat pula gambaran mengenai fungsi dan bentuk ideal QRIS di mata pelaku usaha UMKM. Mereka menggambarkan QRIS sebagai alat pembayaran yang menguntungkan, sebagai alternatif pembayaran, lebih higienis karena dapat mengurangi kontak fisik, mudah digunakan, memudahkan pembayaran, bentuk sederhana, hanya perlu menempatkan $Q R$ code di depan meja kasir. QRIS dipahami sebagai bentuk kode batang digital yang memberi fasilitas pencatatan transaksi digital serta pembayaran digital.

Penelitian ini menguatkan beberapa penelitian sebelumnya yang mengindikasikan bahwa UMKM cenderung mengikuti trend. Sehingga keputusan mereka menggunakan QRIS dipengaruhi orang terdekat, pembeli dan sesama 
pelaku usaha (Suwandi \& Azis, 2018). Temuan penelitian ini mengindikasikan bahwa UMKM cenderung lebih mempercayai rekomendasi teman dekat atau pembeli dalam mengambil keputusan menggunakan QRIS. Penelitian ini juga mengidentifikasi tiga faktor yang dapat menjadi faktor penghambat minat UMKM menggunakan QRIS, yaitu: koneksi/jaringan internet, biaya penggunaan QRIS dan limit transaksi.

\section{SIMPULAN DAN SARAN}

Penelitian ini mengidentifikasikan bahwa intensi UMKM menggunakan QRIS dibentuk oleh, (1) Persepsi kegunaan, (2) Persepsi kemudahan, (3) Pemahaman akan QRIS; (4) Pengaruh pihak luar, yaitu pembeli, teman dekat, dan tokoh terkenal; (5) Persepsi hambatan untuk menggunakan QRIS, yaitu koneksi/jaringan internet, biaya penggunaan, dan limit transaksi. Persepsi positif terhadap QRIS membentuk niat yang kuat untuk menggunakan QRIS. Sebaliknya, persepsi hambatan yang semakin besar akan menurunkan intensi UMKM menggunakan QRIS. Penelitian ini memiliki implikasi bagi para pengusaha maupun lembaga keuangan bank atau non-bank yang akan maupun sedang mengembangkan QRIS. Faktor-faktor yang menentukan minat UMKM menggunakan QRIS perlu dipahami dengan baik, mengingat kontribusi UMKM yang signifikan bagi perkembangan QRIS. QRIS sebaiknya didesain dengan lebih mengoptimalkan fungsi pembayarannya. Selain itu, QRIS juga sebaiknya dilengkapi dengan penambahan limit transaksi atau batas transaksi yang 
memungkinkan UMKM memiliki cukup banyak nominal transaksi. Hal ini akan meningkatkan pengalaman dan persepsi positif UMKM. Dengan diperolehnya pengalaman, manfaat dan persepsi positif terhadap QRIS, diharapkan UMKM akan dengan senang hati menggunakan QRIS dan merekomendasikan kepada teman dan UMKM lainnya.

Perusahaan dan lembaga bank atau non-bank perlu menerapkan strategi yang tepat untuk menarik UMKM. Penelitian ini merekomendasikan penerapan strategi word of mouth, baik secara fisik maupun online. Strategi yang dapat diterapkan untuk memotivasi UMKM menuliskan review positifnya dan merekomendasikan kepada teman usaha, antara lain dengan memberikan apresiasi berupa pelayanan yang baik, bonus, dan hal menarik lainya. Penelitian ini telah berupaya melakukan eksplorasi mendalam atas faktor-faktor yang mempengaruhi minat UMKM menggunakan QRIS dengan mewawancarai hingga 16 pelaku usaha (UMKM) dengan latar belakang penghasilan, jenis usaha, pendapatan dan letak usaha yang berbeda. Upaya ini diharapkan dapat menghasilkan gambaran lebih lengkap dan konferhensif terkait faktor-faktor penentu intensi UMKM menggunakan QRIS. Penelitian ini juga merekomendasikan model hubungan antar variabel-variabel pembentuk intensi dan indikator-indikator variabel laten yang dapat dijadikan panduan penyusunan instrumen kuesioner dan perumusan model yang dapat diuji secara empiris dalam penelitian berikutnya. Akan tetapi, karena penelitian ini hanya difokuskan pada UMKM di kota Denpasar dan pinggir kota Denpasar, temuan penelitian ini mungkin saja kurang relevan untuk konteks daerah lain yang memiliki karakteristik berbeda dengan kota Denpasar dan 
pinggir kota Denpasar. Dengan demikian, untuk menyempurnakan penelitian ini, penelitian berikutnya dapat dilakukan pada konteks kota lain yang memiliki karakteristik berbeda dari kota Denpasar dan pinggir kota Denpasar. Agar dapat digeneralisasi, penelitian berikutnya juga dapat melakukan pengujian model melalui penyebaran kuesioner yang melibatkan responden yang lebih luas.

\section{REFERENSI}

Ahriana, Yani, A., \& Maruf, U. M. M. (2016). Studi Analisis Hubungan Antara Self Efficacy dengan Hasil. Jurnal Pendidikan Fisika, 4(2), 223-238.

Ajzen, I. (1991). The Theory of Planned Behavior. Organizational Behavior and Human Decision Processes, 50(2), 179-211.

Bank Indonesia. (2006). Uang Elektronik. In Bank Indonesia. https://www.bi.go.id/id/edukasi-perlindungan-konsumen/edukasi/produkdan-jasa-sp/uang-elektronik/Pages/default.aspx

Bank Indonesia. (2014). Peraturan Bank Indonesia Nomor 16/8/PBI/2014 tentang Perubahan atas Peraturan Bank Indonesia Nomor 11/12/PBI/2009 tentang Uang Elektronik (Electronic Money). Peraturan BI No 16/8/PBI /2014. https://www.bi.go.id/id/peraturan/sistem-pembayaran/Pages/PBI_16814.aspx

Bank Indonesia. (2019). Blueprint Sistem Pembayaran Indonesia ( BSPI ) 2025. $5-7$.

Carlsson, B., \& Gustavsson, R. (2001). Active Media Technology, 6th International Computer Science Conference, \{AMT\} 2001, Hong Kong, China, December 18-20, 2001, Proceedings. 2252(May 2014). https://doi.org/10.1007/3-540-45336-9

Chakravorti, S., \& Jankowski, C. (2005). Forces shaping the payments environment: A summary of the Chicago Fed's 2005 Payments Conference. Chicago Fed Letter, 219a, 1-9.

Clarysse, B., Wright, M., Bruneel, J., \& Mahajan, A. (2014). Creating value in ecosystems: Crossing the chasm between knowledge and business ecosystems. Research Policy, 43(7), 1164-1176. https://doi.org/10.1016/j.respol.2014.04.014 
Dahlberg, T., Guo, J., \& Ondrus, J. (2015). A critical review of mobile payment research. Electronic Commerce Research and Applications, 14(5), 265-284. https://doi.org/10.1016/j.elerap.2015.07.006

Dahlberg, T., Mallat, N., Ondrus, J., \& Zmijewska, A. (2008). Past, present and future of mobile payments research: A literature review. Electronic Commerce Research and Applications, 7(2), 165-181. https://doi.org/10.1016/j.elerap.2007.02.001

Davis, F. D. (1989). Davis 1989.pdf. In Information Technology. https://doi.org/10.2307/249008

Duncombe, R. (2011). Researching impact of mobile phones for development: Concepts, methods and lessons for practice. Information Technology for Development, 17(4), 268-288. https://doi.org/10.1080/02681102.2011.561279

Evans, D. and P. A., Yu, S., Ibtasam, S., Bank of Ghana, GSMA, Lyons, P., Ov, N. O. N. E. M. B. E. R., Altunbas, Y., Mothobi, O., \& Grzybowski, L. (2017). Impact of mobile money on the payment system in ghana: an econometric analysis. University of Chicago Coase-Sandor Institute for Law \& Economics Research Paper. https://doi.org/10.1145/3209811.3209863

Ezeh, P. C., \& Nwankwo, N. (2018). Factors that Influence the Acceptance of Mobile Money in Nigeria. Journal of Research in Marketing, 8(2), 684. https://doi.org/10.17722/jorm.v8i2.217

Ferdiana, A. M. K., \& Darma, G. S. (2019). Understanding Fintech Through Go Pay. International Journal of Innovative Science and Research Technology, 4(2), 257-260.

Gefen, D., Karahanna, E., \& Straub, D. W. (2003). Trust and TAM in Online Shopping. MIS Quarterly. https://doi.org/10.2307/30036519

goleman, daniel; boyatzis, Richard; Mckee, A., \& Perdana. (2018). Blueprint Sisitem Pembayaran Indonesia 2025. Bank Indonesia: Menavigasi Sistem Pembayaran Nasional di Era Digital. Journal of Chemical Information and Modeling, 53(9), 1689-1699. https://doi.org/10.1017/CBO9781107415324.004

Heider, F. (1944). Social perception and phenomenal causality. Psychological Review. https://doi.org/10.1037/h0055425

Jenkins, B. (n.d.). Developing Mobile Money Ecosystems. Ecosystems. https://citeseerx.ist.psu.edu/viewdoc/download?doi=10.1.1.512.1139\&rep=re p1\&type $=$ pdf 
Khalil Md Nor, \& Pearson, J. M. (2007). The Influence of Trust on Internet Banking Acceptance. Journal of Internet Banking and Commerce. https://doi.org/https://doi.org/10.1080/15332860802004162

Kasali Rhenald. (2018). The Great Shifting. Jakarta: PT Gramedia Pustaka Utama

Lee, I., \& Shin, Y. J. (2018). Fintech: Ecosystem, business models, investment decisions, and challenges. Business Horizons. https://doi.org/10.1016/j.bushor.2017.09.003

Mangeswuri, D. R., Wuryandani, D., Purwanto, N. P., Hendra, S. P., Meilani, H., Sayekti, N. W., \& Rivani, E. (2018). Industri Kreatif, Fintech dan UMKM dalam Era Digital.

Martins, C., Oliveira, T., \& Popovič, A. (2014). Understanding the internet banking adoption: A unified theory of acceptance and use of technology and perceived risk application. International Journal of Information Management, 34(1), 1-13. https://doi.org/10.1016/j.ijinfomgt.2013.06.002

Modelski, G., \& Devezas, T. (2007). Political Globalization is Global Political Evolution. World $\quad$ Futures, 63(5-6), 308-323. https://doi.org/10.1080/02604020701402707

Oye, K. A., Esvelt, K., Appleton, E., Catteruccia, F., Church, G., Kuiken, T., Lightfoot, S. B. Y., McNamara, J., Smidler, A., \& Collins, J. P. (2014). Regulating gene drives. Science, 345(6197), 626-628. https://doi.org/10.1126/science. 1254287

Paula Graça, L. C.-M. (2017). Collaboration in a Data-Rich World. IFIP International Federation for Information Processing 2017, 506(July 2018), 761-774. https://doi.org/10.1007/978-3-319-65151-4

Popovska-Kamnar, N. A. (2014). The use of electronic money and its impact on monetary policy. Journal of Contemporary Economic and Business Issues, 1(2), 79-92.

Prahalad, C. K. (1995). New view of strategy: An interview with C.K. Prahalad. In European Management Journal. 13(2). 131-138

Richard L. Daft. (2010). Era baru manajemen. Jakarta: Salemba Empat.

Rockefeller. (2010). Scenarios for the Future of Technology and International Development. Global Buisiness Network, 1-51.

Sahni, V., \& Slamet, M. (2006). Quantal density functional theory: Wave function arbitrariness of the noninteracting fermion model. International Journal of 
Quantum Chemistry. https://doi.org/10.1002/qua.21150

Saldaña, J. (2013). Coding Manual: constitutions. In International Journal. https://doi.org/10.1017/CBO9781107415324.004

Sarwono, H. A. (2015). Profil Bisnis Usaha Mikro, Kecil Dan Menengah (Umkm). Bank Indonesia Dan LPPI, 1-135.

Secretariat, C. O. P. A. S. S. (2000). SURVEY OF ELECTRONIC MONEY DEVELOPMENTS. Bank for International Settlements Information, Press \& Library Services, 77.

Setiawan, M. I., Surjokusumo, S., Ma'Soem, D. M., Johan, J., Hasyim, C., Kurniasih, N., Sukoco, A., Dhaniarti, I., Suyono, J., Sudapet, I. N., Nasihien, R. D., Mudjanarko, S. W., Wulandari, A., Ahmar, A. S., \& Wajdi, M. B. N. (2018). Business Centre Development Model of Airport Area in Supporting Airport Sustainability in Indonesia. Journal of Physics: Conference Series, 954(1). https://doi.org/10.1088/1742-6596/954/1/012024

Shy, O. (2019). Cashless Stores and Cash Users Oz Shy Working Paper 2019-11 May 2019. 2019(May).https://doi.org/10.29338/wp2019-11a

Suci, Y. R., Tinggi, S., \& Ekonomi, I. (2017). Perkembangan UMKM (Usaha Mikro Kecil Menengah) di Indonesia. Jurnal Ilmiah Fakultasi Ekonomi, Vol. 6(No. 1). https://e-journal.upp.ac.id/index.php/Cano/article/view/1239

Suwandi, M. A., \& Azis, E. (2018). Faktor-Faktor yang Mempengaruhi Penggunaan E-Money pada Generasi Millenials. E-Proceeding of Management, 5(3), 3104-3111.

Teja, A. (2017). Indonesian Fintech Business: New Innovations or Foster and Collaborate in Business Ecosystems? The Asian Journal of Technology Management (AJTM), 10(1), 10-18. https://doi.org/10.12695/ajtm.2017.10.1.2

UU No. 20 Tahun 2008. (2008). UU No. 20 Tahun 2008. UU No. 20 Tahun 2008, $1,1-31$.

Venkatesh, V., Thong, J. Y. L., \& Xu, X. (2016). Unified theory of acceptance and use of technology: A synthesis and the road ahead. Journal of the Association for Information Systems, 17(5), 328-376. https://doi.org/10.17705/1jais.00428

World Economic Forum. (2015). The Future of Fintech: A Paradigm Shift in Small Business Finance. Global Agenda Council on the Future of Financing \& Capital, October, 1-36. 
I Wayan Arta Setiawan dan Luh Putu Mahyuni. Qris di Mata Umkm: Eksplorasi Persepsi.

Yahyapour, N. (2008). Determining factors affecting Internet to adopt banking recommender system. Division of Industrial Marketing and E-Commerce, Master's Thesis, 36, 31-48. 